\title{
Analisis Pembuktian Alat Bukti Closed Circuit Television (CCTV) Sebagai Alat Bukti Petunjuk
}

\author{
William Abraham \\ (Mahasiswa Program S1 Fakultas Hukum Universitas Tarumanagara) \\ (E-mail: william.abraham@ymail.com)
}

\section{Hery Firmansyah}

(Corresponding Author)

(Dosen Fakultas Hukum Universitas Tarumanagara. Meraih Sarjana Hukum pada Fakultas Hukum

Universitas Gadjah Mada, Magister Hukum pada Fakultas Hukum Universitas Gadjah Mada, dan

Magister Administrasi Publik pada Fakultas Administrasi Gadjah Mada)

(E-mail: heryf@fh.untar.ac.id)

\begin{abstract}
Process of proofing is one of the most important in the trial. In the process of proofing, someone could be determined as defendant or not by relating the facts that happened with the available evidence in the trial. Process of proofing refers to Criminal Code Procedure Article 183 which about need minimum of 2 (two) valid evidence and to get Judge's conviction and also refers to Criminal Code Procedure Article 184 which about valid evidence that can use in the trial. Along with the current development that continuously evolving, there is evidences outside of Criminal Code Procedure. Closed Circuit Television is one of many evidences that arranged in Law of Republic Indonesia Number 11 of 2008 concerning Information and Electronic Transaction. Now, Closed Circuit Television often used in trial to give more explanation about unclear facts to make it clear. But, to use Closed Circuit Television as evidence, it needs related to Criminal Code Procedure Article 188. To be able used as valid evidence Closed Circuit Television need to has correlation between facts in the trial and Closed Circuit Television itself.
\end{abstract}

Keywords: Evidence, Closed Circuit Television, Process of Proofing 


\section{PENDAHULUAN}

\section{A. Latar Belakang}

Seiring perkembangannya zaman, kejahatan di Indonesia juga semakin sering terjadi di lingkungan masyarakat. Banyaknya kejahatan tersebut juga mempunyai jenis kejahatan yang bermacam-macam mengikuti perkembangan zaman. Bersamaan dengan hal-hal tersebut, perkembangan teknologi juga berkembang cukup pesat pada zaman ini. Perkembangan teknologi yang berkembang pada zaman ini dapat digunakan sebagai alat bantu untuk mempermudah menghadapi kejahatan-kejahatan yang ada. Dikarenakan kejahatan yang semakin berkembang pada era ini maka diperlukannya pembuktian yang juga harus mengikuti perkembangan untuk mempermudah mengatasi kejahatan yaitu salah satu contohnya pembuktian berupa informasi elektronik.

Pembuktian dapat dikatakan menjadi tahap yang paling penting dalam menentukan proses peradilan pidana yang dikarenakan pada tahap pembuktian tersebut akan ditentukan terbukti atau tidaknya seorang terdakwa melakukan perbuatan pidana sebagaimana yang didakwakan oleh penuntut umum. Tata cara pembuktian tersebut dimuat dan diatur di dalam Undang-Undang Nomor 8 Tahun 1981 tentang Kitab Undang-Undang Hukum Acara Pidana.

Menurut Munir Fuady hukum pembuktian adalah suatu proses, baik dalam acara perdata, acara pidana, maupun acara-acara lainnya, dimana dengan menggunakan alat-alat bukti yang sah, dilakukan tindakan dengan prosedur khusus, untuk mengetahui apakah suatu fakta atau pernyataan, khususnya fakta atau pernyataan yang dipersengketakan di pengadilan, yang diajukan dan dinyatakan oleh salah satu pihak dalam proses pengadilan itu benar atau tidak seperti yang dinyatakan itu. ${ }^{1)}$

\footnotetext{
1) Munir Fuady, Teori Hukum Pembuktian (Pidana dan Perdata), (Jakarta: Citra Aditya Bakti, 2012), hal. 1-2.
} 
Dalam halnya pembuktian, tentu saja harus ada yang membuktikan di dalam proses pembuktian. Membuktikan itu sendiri memiliki maksud ialah meyakinkan Hakim tentang dalil atau dalil-dalil yang dikemukakan dalam suatu persengketaan. ${ }^{2)}$ Dalam proses pembuktian, tentu juga harus adanya bukti yang bersangkutan sesuai yang diatur di dalam Kitab Undang-Undang Hukum Acara Pidana Pasal 184 Ayat (1). Bukti tersebut adalah sesuatu hal (peristiwa dan sebagainya) yang cukup untuk memperlihatkan kebenaran sesuatu hal (peristiwa dan sebagainya). ${ }^{3}$ Ada juga yang mengatakan bahwa evidence (bukti) memiliki arti, yaitu informasi yang memberikan dasar-dasar yang mendukung suatu keyakinan bahwa beberapa bagian atau keseluruhan fakta itu benar. ${ }^{4)}$

Pada Pasal 183 Kitab Undang-Undang Hukum Acara Pidana dikatakan bahwa diperlukan sekurang-kurangnya 2 (dua) alat bukti yang sah untuk hakim menjatuhi pidana serta memperoleh keyakinan apakah tindak pidana tersebut telah benar-benar terjadi dan terdakwalah yang telah melakukan tindak pidana tersebut. Dalam hal ini berarti hakim hanya boleh menjatuhkan pidana pada terdakwa apabila ditemukan 2 (dua) alat bukti yang sah yang dapat membuktikan bahwa terdakwa tersebut telah melakukan kejahatan tindak pidana. Di dalam Kitab Undang-Undang Hukum Acara Pidana Pasal 184 Ayat 1 (satu) terdapat 5 (lima) alat bukti yang dapat dikatakan sah. Dijelaskan juga pada Pasal 184 Ayat 2 (dua) hal yang secara umum sudah diketahui tidak perlu dibuktikan yang berarti jika hal tersebut telah diketahui oleh orang banyak maka hal tersebut tidaklah perlu dibuktikan pada saat persidangan. Sehingga hal-hal yang harus dibuktikan adalah hal-hal yang tercantum pada Pasal 184 Ayat 1 (satu) Kitab Undang-Undang Hukum Acara Pidana. Jenis-jenis alat

\footnotetext{
${ }^{2)}$ R.Subekti, Hukum Pembuktian, Cetakan ke-15, (Jakarta: Pradnya Paramita, 2005), hal. 1.

3) Bambang Waluyo, Sistem Pembuktian Dalam Peradilan Indonesia, (Jakarta: Sinar Grafika, 1992), hal. 1.

4) Eddy O.S. Hiariej, Teori dan Hukum Pembuktian, Cetakan ke-1, (Jakarta: Erlangga, 2012), hal. 2.
} 
bukti tersebut harus dibuktikan kebenarannya karena alat bukti tersebut dapat menjadi peran penting untuk berlangsungnya tahap pembuktian saat persidangan berlangsung yang dapat memudahkan atau memberikan pencerahan bagi penuntut umum untuk menentukan apakah terdakwa tersebut bersalah atau tidak.

Alat bukti sah yang tercantum pada Pasal 184 Ayat 1 (satu) adalah untuk membuktikan kebenaran materil terdakwa apakah ia bersalah atau tidak. Bagi aparat penegak hukum, akan lebih mudah membuktikan apabila saksi dapat membuktikan atau menunjukan kesalahan terdakwa yang telah melakukan kejahatan tindak pidana tersebut. Tetapi sebaliknya, apabila saksi tidak dapat membuktikan atau menunjukan kesalahan terdakwa telah melakukan kejatahatan tindak pidana tersebut, maka aparat penegak hukum akan lebih sulit untuk menelusuri dan membuktikan kebenaran materil tersebut. Pada kesempatan yang Penulis peroleh ini, Penulis akan memberikan beberapa contoh kasus mengenai pembuktian tentang alat bukti Closed Circuit Television (yang selanjutnya akan disebut CCTV).

Pembuktian mengenai CCTV yang terdapat pada kasus Jessica Wongso. Pada kasus tersebut CCTV digunakan oleh hakim sebagai alat bukti petunjuk yang sah. Hakim berpendapat bahwa CCTV yang terdapat di Kafe Olivier bukan sengaja diperuntukkan untuk kasus dalam perkara ini, akan tetapi secara umum sebelumnya telah terpasang ditempat tersebut yang bisa memantau setiap kejadian yang terjadi di lingkungan Kafe Olivier, sehingga CCTV tersebut tidak harus dibuat sendiri oleh Pejabat yang berwenang. ${ }^{5)}$

Adapun kasus lain tentang pembuktian mengenai CCTV yaitu pada kasus Romli Bin Nawawi. Pada kasus ini, Romli mencuri barang-barang milik PT. Medco Energi Kaji. Pencurian yang dilakukan oleh Romli tidak terlihat oleh orang-orang tetapi terdapat CCTV yang merekam kejadian di mana Romli

\footnotetext{
${ }^{5)}$ Indonesia, Putusan Pengadilan Negeri, Nomor:777/PID.B.2016/PN.JKT.PST, hal. 312.
} 
melakukan aksi pencurian tersebut. Hakim berpendapat bahwa rekaman CCTV dalam perkara ini adalah sebagai barang bukti yang sah menurut hukum tetapi tidak dijadikan alat bukti dalam perkara ini. ${ }^{6}$ )

Kasus pembuktian lainnya mengenai CCTV terdapat pada kasus Agus Rismanto Bin Dedi Samsudin. Dalam kasus ini, Agus mencuri 1 (satu) buah motor milik Risa Afrianti. Pada pencurian yang dilakukan oleh Agus, ketika mengetahui terdapat motor yang hilang kemudian operator warnet melihat rekaman CCTV dan terlihat dari CCTV tersebut bahwa Agus mencuri 1 (satu) buah motor. Hakim menimbang bahwa terhadap barang bukti yang diajukan di persidangan berupa 1 (satu) flasdisk rekaman CCTV yang berkaitan dengan perbuatan terdakwa dalam melakukan tindak pidana, maka Hakim menetapkan CCTV sebagai barang bukti dan terlampir dalam berkas perkara. ${ }^{7)}$

Dari beberapa kasus yang terdapat di atas, ditemukan bahwa masih terdapat ketidakpastian terhadap penggunaan CCTV apakah CCTV tersebut dapat dijadikan sebagai alat bukti atau sebagai barang bukti. Sebagaimana kita tahu, tidak adanya ketentuan di dalam Kitab Undang-Undang Hukum Acara Pidana yang mengatur jelas penggunaan CCTV sebagai alat bukti.

Adapun pengaturan lainnya mengenai dokumen elektronik menurut Pasal 5 Ayat 1 (satu) dan Ayat 2 (dua) Undang-Undang No. 11 Tahun 2008 tentang Informasi dan Transaksi Elektronik dikatakan bahwa informasi elektronik dan/atau dokumen elektronik dan/atau hasil cetaknya merupakan alat bukti hukum yang sah, di mana hal tersebut merupakan perluasan dari alat bukti yang sah sesuai dengan Hukum Acara yang berlaku di Indonesia. Tetapi pada Putusan MK No. 20/PUU-XIV/2016 tanggal 7 September 2016 menindaklanjuti permohonan judicial review Undang-Undang Informasi dan Transaksi Elektronik dikatakan bahwa dalam Pasal 5 Ayat 1 (satu) dan Ayat 2 (dua) Undang-Undang Nomor 11 Tahun 2008 tentang Informasi dan Transaksi

\footnotetext{
${ }^{6)}$ Indonesia, Putusan Pengadilan Negeri, Nomor:11/PID/B/2015/PN.SKY, hal. 6.

${ }^{7)}$ Indonesia, Putusan Pengadilan Negeri, Nomor: 127/PID.B/2015/PN.TLG, hal. 13.
} 
Elektronik bertentangan dengan Undang-Undang Dasar Negara Republik Indonesia Tahun 1945 sepanjang tidak dimaknai khususnya frasa "Informasi Elektronik dan/atau Dokumen Elektronik" sebagai alat bukti dilakukan dalam rangka penegakan hukum atas permintaan kepolisian, kejaksaan, dan/atau institusi penegak hukum lainnya yang ditetapkan berdasarkan undang-undang sebagaimana ditentukan dalam Pasal 31 Ayat 3 (tiga) Undang-Undang Nomor 11 Tahun 2008 tentang Informasi dan Transaksi Elektronik.

Berdasarkan uraian latar belakang yang telah dikemukakan di atas, maka Penulis merasa tertarik untuk mengkaji mengenai kasus-kasus mengenai pembuktian CCTV tersebut secara komperhensif dan menuangkannya dalam bentuk proposal skripsi dengan judul "ANALISIS PEMBUKTIAN ALAT BUKTI CLOSED CIRCUIT TELEVISION (CCTV) SEBAGAI ALAT BUKTI PETUNJUK."

\section{B. Perumusan Masalah}

Berdasarkan apa yang telah diuraikan pada latar belakang, permasalahan yang diteliti dalam penulisan ini yaitu:

1. Bagaimana alat bukti CCTV dapat dijadikan sebagai alat bukti petunjuk sesuai dengan Pasal 188 Kitab Undang-Undang Hukum Acara Pidana dikaitkan dalam teori pembuktian perkara pidana?

2. Bagaimana dasar pertimbangan hakim dalam menggunakan CCTV sebagai alat bukti?

\section{PEMBAHASAN}

\section{A. Data Hasil Wawancara}

\section{Andi Widiatno}

Dalam wawancara Peneliti dengan Andi Widiatno mengenai pembahasan yang sesuai dengan skripsi yang Peneliti teliti, beliau menjelaskan terlebih dahulu pengertian dari informasi elektronik dan/atau 
dokumen elektronik beserta hasil cetaknya merupakan alat bukti hukum yang sah sesuai dengan hukum acara yang berlaku di Indonesia sesuai dengan Pasal 5 Ayat (1) dan (2) Undang-Undang Nomor 11 Tahun 2008 Tentang Informasi dan Transaksi Elektronik. Beliau mengartikan bahwa informasi elektronik dengan dokumen elektronik hampir mempunyai kesamaan pengertian, namun yang menjadi perbedaan adalah dokumen elektronik pada saat informasi elektronik tersebut dapat dipakai berulangulang. Beliau juga memberikan contoh dari informasi elektronik tersebut adalah film, video, siaran televisi, ataupun broadcast. Pada saat film, video, siaran televisi, ataupun broadcast tersebut disimpan, maka informasi elektronik seperti film, video, siaran televisi, ataupun broadcast berubah menjadi dokumen elektronik. Jadi, sifat dari dokumen elektronik tersebut adalah sebagai dokumentari atau sebagai arsip. Hasil cetak menurut beliau adalah saat informasi atau dokumen elektronik itu di print out. Mengenai alat bukti hukum yang sah, beliau berpendapat bahwa syarat sahnya tersebut mempunyai syarat, yaitu sesuai dengan Putusan Mahkamah Konstitusi No. 20/PUU-XIV/2016 bahwa alat bukti tersebut harus dibuat oleh pihak yang berwenang ataupun memang sejak semula ditujukan untuk menjadi alat bukti. Sehingga, tidak semua informasi elektronik dan/atau dokumen elektronik beserta hasil cetaknya merupakan alat bukti hukum yang sah. Beliau juga mengatakan bahwa informasi elektronik dan/atau dokumen elektronik beserta hasil cetaknya adalah sebagai perluasan dari hukum acara yang berlaku di Indonesia, sehingga sifatnya adalah melengkapi dari Pasal 184 Kitab Undang-Undang Hukum Acara Pidana karena sebagai perluasan. Kembali pada CCTV, bahwa yang melakukan pemasangan terhadap CCTV tersebut hanya boleh dilakukan oleh instansi yang berwenang yang diatur oleh Undang-Undang. Sehingga, contohnya dari kasus pembunuhan Mirna bahwa CCTV yang terdapat dalam kasus pembunuhan Mirna tersebut tidak dapat dijadikan alat bukti, karena CCTV 
diperoleh sebelum proses penyelidikan, kecuali saat penyelidikan CCTV tersebut baru digunakan dan terlebih lagi bahwa sesuai dengan Putusan Mahkamah Konstitusi No. 20/PUU-XIV/2016 harus adanya permintaan atas pihak kepolisian, kejaksaan, dan/atau institusi penegak hukum lainnya agar diperolehnya alat bukti elektronik tersebut menjadi alat bukti hukum yang sah. ${ }^{8)}$

\section{Abdul Fickar Hadjar}

Pada wawancara Peneliti bersama dengan Abdul Fickar Hadjar yang merupakan pakar ahli pidana. Beliau pertama-tama mengatakan bahwa Pasal 5 jo Pasal 44 Undang-Undang Nomor 11 Tahun 2008 Tentang Informasi dan Transaksi Elektronik adalah jika disederhanakan mempunyai pengertian mengenai informasi elektronik dan/atau dokumen elektronik atau hasil cetaknya merupakan alat bukti hukum yang sah kecuali surat yang oleh Undang-Undang diatur bentuknya dan surat-surat yang harus dibuat oleh akta notaris. Namun, sekarang terdapat Putusan Mahkamah Konstitusi No. 20/PUU-XIV/2016 dinyatakan juga sebagai perluasan, tetapi sebenarnya rekaman yang dimaksud oleh Undang-Undang Nomor 11 Tahun 2008 Tentang Informasi dan Transaksi Elektronik tersebut itu merupakan rekaman yang berkaitan dengan transaksi elektronik bukan rekaman CCTV karena pada kasusnya Setya Novanto itu ditujukan untuk rekaman suara yang direkam oleh direktur privotnya. Tetapi, dalam Putusan Mahkamah Konstitusi itu memperluas arti rekaman tersebut tidak hanya dalam transaksi elektronik tetapi juga rekaman yang di luar itu. Rekaman tersebut dapat menjadi alat bukti sepanjang dilakukan atau diminta oleh penegak hukum yang dalam hal ini adalah kepolisian, kejaksaan, atau badan penegak hukum lainnya. Mengenai hal tersebut, dalam Putusan Mahkamah Konstitusi tidak menjelaskan lebih rinci

\footnotetext{
8) Peneliti, Wawancara, dengan Andi Widiatno, (Jakarta: Universitas Trisakti, 13 November 2018).
} 
terhadap permintaan yang dilakukan oleh penegak hukum itu apakah permintaan perekaman atau hasil rekaman tersebut. Maka, menurut pendapat beliau yaitu arti dari permintaan yang terdapat dalam Putusan Mahkamah Konstitusi tersebut adalah hasil rekaman yang sepanjang dalam suatu perkara pidana jika hasil rekaman tersebut diminta oleh penegak hukum maka menjadi alat bukti hukum yang sah. Karena, jika permintaan itu adalah untuk merekam maka dalam suatu perkara pidana pasti akan terlambat. Tetapi, menurut beliau tetap saja CCTV itu selain oleh UndangUndang Nomor 11 Tahun 2008 Tentang Informasi dan Transaksi Elektronik itu diartikan sebagai alat bukti hukum yang sah, CCTV juga bisa menjadi perluasan dari Pasal 184 Kitab Undang-Undang Hukum Acara Pidana. Mengenai kedudukannya di pengadilan, seperti juga alat bukti yang lain yang diatur oleh Pasal 184 Kitab Undang-Undang Hukum Acara Pidana bahwa Hakim boleh memustukan atas kewenangannya status dari alat bukti tersebut apakah alat bukti tersebut relevan atau tidak relevan. Dengan demikian, CCTV ketika dibawa ke pengadilan bisa sangat mungkin menerima sebagai alat bukti petunjuk atau sebaliknya bahwa CCTV tersebut tidak ada kaitannya dengan peristiwa pidana tersebut dan tidak sah menjadi alat bukti. Tetapi, di dalam yurisprudensi di pengadilan dalam beberapa putusan mengenai CCTV, CCTV itu digunakan sebagai alat untuk mengkonfirmasi dengan alat bukti yang lain apakah alat bukti yang lain sesuai atau tidak dengan rekaman CCTV tersebut. Sehingga, CCTV bisa dijadikan barang bukti perluasan yang kemudian dapat dijadikan sebagai alat bukti petunjuk untuk memastikan ada atau tidaknya tindak pidana. Mengenai, jika dikaitkannya dengan teori pembuktian dalam hukum pidana yaitu bahwa dalam Pasal 183 Kitab Undang-Undang Hukum Acara Pidana dibutuhkan 2 (dua) alat bukti yang dapat menimbulkan keyakinan Hakim. Petunjuk itu merupakan bagian dari alat bukti, jika petunjuk itu berdiri sendiri dan diperkuat alat bukti yang lain yang juga 
menimbulkan keyakinan Hakim, maka dapat dipakai sebagai dasar memutus bahwa bersalah atau tidaknya seseorang. Adapun beliau berpendapat yang menjadi kesulitan Hakim dalam menggunakan CCTV tersebut sebagai alat bukti adalah terletak pada otentiktasnya, karena CCTV tersebut dapat dimanipulasi. Namun, sekarang dalam perkembangan teknologi bahwa rekaman yang asli itu berada pada drive dari CCTV tersebut. Sehingga, pada sekarang ini Hakim sudah tidak begitu kesulitan mengenai otentik atau tidak otentiknya dari CCTV tersebut karena adanya drive yang menyimpan video rekaman asli dari CCTV tersebut. ${ }^{9}$

\section{Aprima Suar}

Adapun Peneliti juga melakukan wawancara bersama dengan Aprima Suar. Beliau mengatakan bahwa CCTV pada Pasal 184 Kitab UndangUndang Hukum Acara Pidana masuk ke dalam alat bukti petunjuk. Ketika CCTV tersebut dilihat, kemudian petugas CCTV tersebut juga harus ditulis di dalam berita acara sebagai saksi atas CCTV tersebut apakah rekaman atas CCTV tersebut sesuai dengan peristiwa yang terjadi pada saat itu. Dan jika berkaitan dengan CCTV tentunya bisa didapatkan petunjuk, karena jika perbuatan Tersangka sesuai maka dapat dikuatkan oleh bukti CCTV. Kemudian, dekoder dari CCTV tersebut harus diperiksa oleh laboratorium forensik kriminal. Mengenai Putusan Mahkamah Konstitusi No. 20/PUUXIV/2016 mengenai penegakan hukum atas permintaan kepolisian, kejaksaan, ataupun badan penegak hukum lainnya menurut beliau yaitu bahwa yang dimaksud permintaan adalah permintaan atas hasil rekaman CCTV tersebut dan juga disertai permintaan dekoder CCTV tersebut. Beliau juga menambahkan bahwa bila diperlukan petugas laboratorium forensik dimasukan di dalam berita acara juga sebagai ahli sehingga lebih menguatkan alat bukti tersebut. Menurut beliau jika CCTV yang awalnya

\footnotetext{
${ }^{9)}$ Peneliti, Wawancara, dengan Abdul Fickar Hadjar, (Jakarta: Universitas Trisakti, 13 November 2018).
} 
merupakan hanya sebagai barang bukti tetapi jika sebelumnya telah diperoleh keterangan saksi ataupun keterangan terdakwa yang memberikan pengakuan dan sesuai dengan apa yang direkam oleh CCTV tersebut, maka CCTV yang awalnya sebagai barang bukti, maka Hakim dapat menjadikannya alat bukti petunjuk. Beliau juga berpendapat bahwa Hakim dalam era setelah adanya CCTV ini, Hakim lebih mudah dalam menentukan seseorang bersalah atau tidaknya karena yang pada awalnya sebelum dikenal era CCTV, jika sesuatu peristiwa pidana itu gelap tidak ada yang melihat, maka dengan adanya CCTV membuat peristiwa pidana lebih terang. Tetapi, kembali lagi bahwa alat bukti petunjuk itu adalah terdapat di pemikiran Hakim, jika Hakim tidak yakin maka Hakim boleh tidak menggunakan petunjuk tersebut sebagai alat bukti tetapi jika Hakim yakin bahwa CCTV tersebut telah sesuai dengan alat bukti lainnya, maka Hakim dapat menggunakan CCTV tersebut sebagai alat bukti. ${ }^{10)}$

\section{Benedictus Bambang Nurhadi}

Peneliti pada kali ini melakukan wawancara bersama dengan Benedictus Bambang Nurhadi, beliau menyatakan bahwa informasi elektronik dan/atau dokumen elektronik atau hasil cetaknya merupakan alat bukti yang sah sesuai dengan hukum acara yang berlaku di Indonesia. Dalam hal ini CCTV adalah bagian dari hal tersebut sehingga dapat digunakan sebagai alat bukti yang sah. Menurut beliau pada Putusan Mahkamah Konstitusi No. 20/PUU-XIV/2016 yang terdapatnya frasa penegakan hukum atas permintaan pihak kepolisian, kejaksaan, ataupun badan penegak hukum lainnya adalah yang dimaksud dari permintaan tersebut yaitu permintaan atas hasil rekaman CCTV. Karena, jika permintaan pemasangan CCTV menurut beliau, pada dasarnya CCTV tidak digunakan untuk penyadapan tetapi untuk keamanan. Dan tidak adanya 2018).

${ }^{10)}$ Peneliti, Wawancara, dengan Aprima Suar, (Jakarta: Universitas Tarumanagara, 14 November 
peraturan bahwa restoran, hotel, ataupun tempat keramaian harus memasang CCTV, yang artinya pemasangan CCTV bersifat sukarela yaitu pemilik tempat itu yang memasangnya sendiri dengan tujuan keamanan dari tempat tersebut. Apabila terjadi peristiwa hukum di dalam tempat tersebut yang ternyata ada CCTV nya, maka CCTV tersebut dipakai untuk melengkapi penyidikan yaitu melalui permintaan hasil rekaman CCTV tersebut yang sehingga rekaman CCTV tersebut dapat digunakan sebagai alat bukti petunjuk. Tetapi, alat bukti petunjuk tersebut harus dilengkapi dengan alat bukti lainnya sesuai dengan Pasal 188 Kitab Undang-Undang Hukum Acara Pidana. Mengenai rekaman CCTV yang dijadikan sebagai barang bukti yang sah, menurut beliau jika rekaman CCTV itu berkaitan dengan keterangan saksi maupun keterangan terdakwanya, maka Hakim dapat menggunakan rekaman CCTV sebagai alat bukti petunjuk karena mempunyai keterkaitan terhadap keterangan saksi maupun keterangan terdakwanya. Beliau juga berpendapat bahwa jika CCTV dikaitkan dengan teori pembuktian pidana, bahwa pada Pasal 183 Kitab Undang-Undang Hukum Acara Pidana yaitu dibutuhkan minimal 2 (dua) alat bukti hukum yang sah yang menimbulkan keyakinan Hakim. Sehingga, haruslah terpenuhi dahulu 2 (dua) alat bukti tersebut. Jika, CCTV itu menjadi alat bukti petunjuk yang menguatkan dengan dikuatkan oleh keterangan saksi ataupun keterangan terdakwa, maka CCTV itu dapat digunakan sebagai alat bukti. Jika, sudah terpenuhinya 2 (dua) alat bukti hukum yang sah, Hakim dapat memutuskan dengan keyakinan yang timbul. Adapun, kesulitan Hakim dalam menggunakan CCTV adalah jika tidak ditemukan alat bukti lainnya atau tidak ada keterangan yang terkait dengan CCTV tersebut. Beliau berpendapat bahwa jika dalam suatu peristiwa hanya didapat CCTV saja yang tentunya menimbulkan kesulitan Hakim dalam penggunaan CCTV menjadi alat bukti karena tidak ada dikuatkan oleh alat bukti lainnya. Petunjuk itu juga tidak dapat menjadi alat bukti tunggal, 
sehingga diperlukannya keterangan dari alat bukti lainnya untuk menguatkan dari petunjuk itu sendiri. ${ }^{11)}$

\section{B. Analisis}

1. Alat bukti CCTV dapat dijadikan sebagai alat bukti petunjuk sesuai dengan Pasal 188 Kitab Undang-Undang Hukum Acara Pidana dikaitkan dalam teori pembuktian perkara pidana

Dalam hukum pidana dikenal adanya beban pembuktian. Beban pembuktian tersebut dibagi atas beban pembuktian pada Penuntut Umum dan beban pembuktian pada Terdakwa. Di mana dalam beban pembuktian pada Penuntut Umum, Penuntut Umum yang harus mempersiapkan barangbarang bukti dan alat-alat bukti untuk dihadirkan di persidangan guna meyakinkan Hakim bahwa Terdakwa memang melakukan suatu tindak pidana sebagaimana didakwakan oleh Penuntut Umum. Dalam beban pembuktian pada Terdakwa, Terdakwa yang harus menghadirkan barangbarang bukti dan alat-alat bukti guna membuktikan bahwa ia tidak melakukan perbuatan pidana sebagaimana yang didakwakan oleh Penuntut Umum. Mengenai beban pembuktian dalam hukum pidana tersebut bahwa pembuktian juga didasarkan pada alat-alat bukti yang tercantum dalam Pasal 184 Ayat (1) Kitab Undang-Undang Hukum Acara Pidana. Alat-alat bukti yang dimaksud dalam Pasal 184 Ayat (1) Kitab Undang-Undang Hukum Acara Pidana adalah keterangan saksi, keterangan ahli, surat, petunjuk, dan keterangan terdakwa. Maka, yang dinilai mempunyai kekuatan pembuktian adalah alah-alat bukti yang tercantum dalam Pasal 184 Ayat (1) Kitab Undang-Undang Hukum Acara Pidana. Diaturnya mengenai alat-alat bukti yang tercantum dalam Pasal 184 Ayat (1) Kitab Undang-Undang Hukum Acara Pidana tersebut dalam perkara pidana membuat alat-alat bukti tersebut mempunyai sifat yang terbatas, sehingga

11 ) Peneliti, Wawancara, dengan Benedictus Bambang Nurhadi, (Jakarta: Universitas Tarumanagara, 19 November 2018). 
jika terdapat barang bukti lain yang tidak sesuai dengan yang dimaksud oleh Pasal 184 (1) Kitab Undang-Undang Hukum Acara Pidana, maka alat bukti tersebut tidak mempunyai kekuatan pembuktian karena tidak sesuai dengan kualifikasi sebagaimana diatur oleh Pasal 184 Ayat (1) Kitab Undang-Undang Hukum Acara Pidana.

Tetapi, karena perkembangan zaman yang begitu pesat di zaman sekarang ini, alat-alat bukti yang tercantum dalam Pasal 184 Kitab Undang-Undang Hukum Acara Pidana tidak dapat mengikuti pesatnya perkembangan zaman yang terjadi sekarang ini. Karena, semakin berkembangnya zaman pada sekarang ini, semakin berkembangnya juga jenis-jenis kejahatan yang terjadi pada lingkungan masyarakat. Sehingga, dibutuhkannya juga alat-alat bukti yang mengikuti perkembangan zaman untuk mempermudah mengungkap kejahatan yang terjadi sekarang ini terutama dalam halnya pembuktian. Adanya Undang-Undang Nomor 11 Tahun 2008 Tentang Informasi dan Transaksi Elektronik membuat adanya perkembangan terhadap teknologi yang sangat dibutuhkan pada zaman sekarang ini karena perkembangan teknologi sangat dapat membantu untuk mengungkap suatu kejahatan terutama pada perkara-perkara pidana.

Pada Pasal 5 Undang-Undang Nomor 11 Tahun 2008 Tentang Informasi dan Transaksi Elektronik yang pada Ayat (1) nya menyatakan bahwa informasi elektronik dan/atau dokumen elektronik dan/atau hasil cetaknya merupakan alat bukti hukum yang sah. Dan pada Ayat (2) menyatakan bahwa informasi elektronik dan/atau dokumen elektronik dan/atau hasil cetaknya sebagaimana dimaksud pada Ayat (1) merupakan perluasan dari alat bukti yang sah sesuai dengan Hukum Acara yang berlaku di Indonesia. Dengan adanya Pasal 5 Ayat (1) dan (2) UndangUndang Nomor 11 Tahun 2008 Tentang Informasi dan Transaksi Elektronik tersebut menjadi perkembangan dari alat-alat bukti diluar 
sebagaimana yang diatur oleh Pasal 184 Kitab Undang-Undang Hukum Acara Pidana.

Dalam pembahasan ini, CCTV adalah salah satu barang bukti elektronik yang disita saat proses penyidikan dan selanjutnya terlampir dalam berkas perkara. CCTV juga menjadi barang bukti elektronik juga dinyatakan oleh Undang-Undang Nomor 11 Tahun 2008 Tentang Informasi dan Transaksi Elektronik karena CCTV termasuk pada apa yang dinyatakan oleh Ayat (1) bahwa CCTV merupakan suatu informasi elektronik dan/atau dokumen elektronik yang dapat dijadikan sebagai alat bukti hukum yang sah. CCTV dapat dikatakan sebagai barang bukti elektronik karena CCTV adalah dokumen yang berbentuk video atau berisikan gambar-gambar yang bergerak yang menerangkan terhadap suatu kejadian tertentu. CCTV yang berisikan dokumen dalam bentuk video atau gambar-gambar bergerak tersebut dipejelas juga oleh Pasal 1 butir 1 dan 4 Undang-Undang Nomor 11 Tahun 2008 Tentang Informasi dan Transaksi Elektronik sehingga lebih memperkuat bahwa CCTV tersebut termasuk dalam barang bukti elektronik.

Namun, sekarang terdapat Putusan Mahkamah Konstitusi Nomor. 20/PUU-XIV/2016 dinyatakan juga sebagai perluasan dari Pasal 5 Ayat (1) dan (2) Undang-Undang Nomor 11 Tahun 2008 Tentang Informasi dan Transaksi Elektronik. Dalam wawancara saya bersama Abdul Fickar Hadjar, beliau menyatakan bahwa sebenarnya yang dimaksud rekaman dalam Undang-Undang Nomor 11 Tahun 2008 Tentang Informasi dan Transaksi Elektronik adalah rekaman yang berkaitan dengan transaksi elektronik bukan rekaman CCTV karena dalam Putusan Mahkamah Konstitusi Nomor. 20/PUU-XIV/2016 adalah mengenai kasus Setya Novanto. Tetapi, Putusan Mahkamah Konstitusi Nomor. 20/PUUXIV/2016 memperluas arti dari rekaman tersebut tidak hanya rekaman yang mengenai transaksi elektronik tetapi juga rekaman yang di luar itu. 
Sehingga, setelah adanya Putusan Mahkmah Konstitusi Nomor. 20/PUUXIV/2016 rekaman CCTV dapat dipergunakan di persidangan guna untuk memberikan pencerahan terhadap sesuatu perkara pidana.

Kembali pada pembuktian dalam hukum pidana, sebagaimana kita tahu bahwa alat-alat bukti yang dinyatakan sah sesuai dengan Pasal 184 Ayat (1) Kitab Undang-Undang Hukum Acara Pidana adalah keterangan saksi, keterangan ahli, surat, petunjuk, dan keterangan terdakwa. Di mana pada pembahasan kali ini Peneliti lebih membahas terhadap alat bukti petunjuk. Pada Pasal 188 Ayat (1) Kitab Undang-Undang Hukum Acara Pidana menyatakan bahwa petunjuk adalah perbuatan, kejadian atau keadaan, yang karena persesuaiannya, baik antara yang satu dengan yang lain, maupun dengan tindak pidana itu sendiri, menandakan bahwa telah terjadi suatu tindak pidana dan siapa pelakunya. Dan pada Pasal 188 (2) Kitab UndangUndang Hukum Acara Pidana menyatakan bahwa petunjuk hanya dapat diperoleh dari keterangan saksi, surat, dan keterangan terdakwa. Sehingga, alat bukti petunjuk yang dalam hal ini harus mempunyai keterkaitan terhadap keterangan saksi, surat, dan keterangan terdakwa yang selanjutnya baru dapat dijadikan sebagai alat bukti petunjuk yang sah.

Menurut pendapat Peneliti, bahwa CCTV dapat dipergunakan sebagai alat bukti petunjuk, jika CCTV tersebut mempunyai keterkaitan antara keterangan saksi, surat, dan keterangan terdakwa sebagaimana dinyatakan oleh Pasal 188 Ayat (2) Kitab Undang-Undang Hukum Acara Pidana. Dengan adanya keterkaitan antara keterangan saksi, surat, dan keterangan terdakwa dengan CCTV itu sendiri, maka CCTV tersebut dapat menunjang sebagai petunjuk dari apa yang sudah dinyatakan oleh keterangan saksi, surat, dan keterangan terdakwa. Seperti yang dikatakan Abdul Fickar Hadjar dalam wawancara saya dengan beliau, beliau menyatakan bahwa CCTV itu digunakan sebagai alat untuk mengkonfirmasi dengan alat bukti yang lain apakah alat bukti yang lain sesuai atau tidak dengan rekaman 
CCTV tersebut. Sehingga, CCTV bisa dijadikan barang bukti perluasan yang kemudian dapat dijadikan sebagai alat bukti petunjuk untuk memastikan ada atau tidaknya tindak pidana. Adapun narasumber lainnya yang saya wawancarai yaitu Benedictus Bambang Nurhadi dan Aprima Suar juga menyatakan hal yang serupa yaitu jika CCTV tersebut adalah untuk memastikan dan memperjelas apa yang telah diperoleh dari keterangan saksi, surat, maupun keterangan terdakwa, apakah keterangan saksi, surat, maupun keterangan terdakwa sesuai atau tidak dengan CCTV tersebut yang jika mempunyai kesesuaian maka CCTV tersebut dapat dipergunakan sebagai alat bukti dalam kasus tersebut.

Dalam pembahasan ini Peneliti mempunyai beberapa contoh kasus yang menggunakan CCTV sebagai salah satu pembuktian di dalam persidangan yang akan Peneliti kaitkan dalam bentuk tabel sesuai dengan Pasal 188 Kitab Undang-Undang Hukum Acara Pidana, yaitu sebagai berikut.

\begin{tabular}{|c|c|c|c|}
\hline & $\begin{array}{c}\text { Keterangan } \\
\text { Saksi }\end{array}$ & Surat & $\begin{array}{c}\text { Keterangan } \\
\text { Terdakwa }\end{array}$ \\
\hline Putusan Nomor & $\sqrt{|c|}$ & \multicolumn{2}{|c|}{} \\
\hline 777/PID.B/2016/PN.JKT.PST & $\sqrt{ }$ & & \multicolumn{2}{|c|}{} \\
\hline 11/PID/B/2015/PN.SKY & $\sqrt{ }$ & & \multicolumn{2}{|c|}{} \\
\hline Putusan Nomor & $\sqrt{ }$ & & \multicolumn{2}{|c|}{} \\
\hline 127/PID.B/2015/PN.TLG & & & \\
\end{tabular}


Dari tabel yang Peneliti telah uraikan di atas, maka dapat di lihat penggunaan CCTV dalam Putusan Nomor 777/PID.B/2016/PN.JKT.PST, Putusan Nomor 11/PID/B/2015/PN.SKY, maupun Putusan Nomor 127/PID.B/2015/PN.TLG bahwa CCTV tersebut adalah alat bukti perluasan yang dalam putusan-putusan tersebut merupakan perluasan dari alat bukti petunjuk. Tetapi, penggunaan CCTV sebagai alat bukti petunjuk tersebut tidak semata-mata ditentukan begitu saja oleh Hakim. Tetapi sesuai dengan tabel di atas, harus terdapat alat-alat bukti lainnya yang terlebih dahulu ditemukan, yang pada kasus-kasus di atas adalah ditemukannya alat bukti keterangan saksi dan keterangan terdakwa. Sehingga, setelah ditemukannya alat bukti keterangan saksi dan keterangan terdakwa, baru dikaitkan dengan apa yang terdapat dalam CCTV tersebut, apakah CCTV tersebut sesuai dengan apa yang dinyatakan oleh alat bukti keterangan saksi dan keterangan terdakwa. Jika, terdapat keterkaitan antara CCTV dengan keterangan saksi dan keterangan terdakwa, CCTV dapat dipergunakan sebagai alat bukti petunjuk karena memperjelas dari apa yang dinyatakan oleh keterangan saksi dan keterangan terdakwa. Tetapi sebaliknya, jika terhadap suatu kasus tertentu CCTV tidak mempunyai keterkaitan antara keterangan saksi, surat, dan keterangan terdakwa sebagaimana dinyatakan oleh Pasal 188 Kitab Undang-Undang Hukum Acara Pidana, maka CCTV tidak dapat dijadikan sebagai alat bukti petunjuk karena, CCTV itu sendiri tidak memperjelas dari apa yang dinyatakan oleh keterangan saksi, surat, dan keterangan terdakwa sehingga tidak dapat dipergunakan menjadi alat bukti petunjuk. Pada dasarnya, bahwa alat bukti petunjuk harus mempunyai keterkaitan ataupun diperoleh dari keterangan saksi, surat, dan keterangan terdakwa barulah alat bukti petunjuk itu mempunyai kekuatan hukum sebagai alat bukti yang berdiri sendiri. 
Jika alat bukti petunjuk tersebut dikaitkan dengan teori pembuktian dalam hukum pidana, di mana teori pembuktian dalam hukum pidana adalah sesuai dengan Pasal 183 Kitab Undang-Undang Hukum Acara Pidana yang menyatakan bahwa pembuktian harus dengan ditemukannya sekurang-kurangnya 2 (dua) alat bukti yang sah baru Hakim dapat memperoleh keyakinannya bahwa tindak pidana tersebut telah benar-benar terjadi dan Terdakwa yang benar telah melakukannya. Dalam halnya beberapa contoh kasus di atas yang Peneliti telah uraikan dengan tabel, maka jika alat bukti CCTV sebagai alat bukti petunjuk dikaitkan dengan teori pembuktian dalam hukum pidana, pertama-tama harus dilihat apakah CCTV tersebut yang dijadikan sebagai alat bukti petunjuk mempunyai keterkaitan atau diperoleh dari keterangan saksi, surat, dan keterangan terdakwa sebagaimana dinyatakan oleh Pasal 188 Kitab Undang-Undang Hukum Acara Pidana. Jika, CCTV tersebut mempunyai keterkaitan ataupun diperoleh dari keterangan saksi, surat, dan keterangan terdakwa, maka CCTV dapat dijadikan alat bukti petunjuk. Dikaitkan dengan teori pembuktian dalam hukum pidana, yaitu di mana dibutuhkannya sekurangkurangnya 2 (dua) alat bukti hukum yang sah, jika sudah ditemukannya alat-alat bukti lain sebagaimana dinyatakan di Pasal 184 (1) Kitab UndangUndang Hukum Acara Pidana dan terlebih jika ditemukannya alat bukti berupa keterangan saksi, surat, dan keterangan terdakwa dan jika CCTV sebagai alat bukti petunjuk itu diperoleh dari keterangan saksi, surat, dan keterangan terdakwa, maka Hakim berarti sudah memperoleh sekurangkurangnya 2 (dua) alat bukti hukum yang sah yang salah satunya adalah alat bukti CCTV yang dijadikan sebagai alat bukti petunjuk.

Sehingga, Peneliti berpendapat sama dengan narasumber yang menyatakan jika CCTV sebagai alat bukti petunjuk sudah diperoleh sebagaimana dinyatakan oleh Pasal 188 Kitab Undang-Undang Hukum Acara Pidana, maka CCTV sebagai alat bukti petunjuk telah memenuhi 
syarat untuk dijadikan alat bukti yang berdiri sendiri yang jika dikaitkan dengan teori pembuktian dalam hukum pidana, maka CCTV dapat dipergunakan oleh Hakim untuk mengisi sekurang-kurangnya 2 (dua) alat bukti hukum yang sah sebagaimana dinyatakan oleh Pasal 183 Kitab Undang-Undang Hukum Acara Pidana. Dengan demikian, CCTV merupakan alat bukti petunjuk yang sah dan juga memenuhi teori pembuktian dalam hukum pidana.

\section{Pertimbangan Hakim dalam menggunakan CCTV sebagai alat bukti}

Pertimbangan Hakim sering dikaitkan dengan teori keyakinan Hakim, di mana dalam teori keyakinan Hakim terdapat beberapa jenis yaitu pembuktian berdasar keyakinan Hakim semata (conviction in time), keyakinan Hakim atas alasan-alasan yang logis (la conviction raisonee), pembuktian berdasarkan Undang-Undang secara positf (positief wettelijk bewijs theorie), dan pembuktian berdasarkan Undang-Undang secara negatif (negatief wettelijk bewijs theorie). Di Indonesia, pertimbangan Hakim sangat dipengaruhi oleh salah satu dari 4 (empat) teori keyakinan Hakim di atas yaitu pembuktian berdasarkan Undang-Undang secara negatif. Teori pembuktian berdasarkan Undang-Undang secara negatif tersebut harus berdasar pada Pasal 183 Kitab Undang-Undang Hukum Acara Pidana dan ditentukan pembukitan harus didasarkan pada UndangUndang, yaitu alat-alat bukti yang dinyatakan di Pasal 184 Ayat (1) Kitab Undang-Undang Hukum Acara Pidana. Dengan sistem seperti ini, maka pemidanaan dapat dikatakan sebagai sistem pembuktian ganda yaitu berdasarkan Undang-Undanag dan keyakinan Hakim di mana keyakinan Hakim yang timbul harus diperoleh dari Undang-Undang. Digunakannya teori pembuktian berdasarkan Undang-Undang secara negatif karena pada dasarnya sesuai dengan Pasal 183 Kitab Undang-Undang Hukum Acara Pidana dinyatakan Hakim hanya boleh menjatuhkan pidana jika telah ditemukannya sekurang-kurangnya 2 (dua) alat bukti hukum yang sah dan 
Hakim dapat memperoleh keyakinan bahwa telah benar-benar terjadi tindak pidana tersebut dan Terdakwa yang telah melakukannya. Secara tidak langsung, Pasal 183 Kitab Undang-Undang Hukum Acara Pidana tersebut sesuai dengan teori pembuktian berdasarkan Undang-Undang secara negatif.

Dengan menggunakan teori pembuktian berdasarkan Undang-Undang secara negatif yang juga bersesuaian dengan Pasal 183 Kitab UndangUndang Hukum Acara Pidana, maka Hakim tidak dapat menjatuhkan suatu hukuman pidana kepada Terdakwa apabila tidak diperolehnya sekurangkurangnya 2 (dua) alat bukti hukum yang sah sebagaimana alat bukti hukum yang sah tercantum pada Pasal 184 (1) Kitab Undang-Undang Hukum Acara Pidana. Setelah diperolehnya sekurang-kurangnya 2 (dua) alat bukti hukum yang sah, Hakim baru dapat bisa memperoleh keyakinannya dan menyatakan seseorang telah melakukan perbuatan pidana. Sehingga, makna dari keyakinan Hakim tersebut timbul bukan atas dasar perasaan Hakim, tetapi sudah timbul berdasarkan alat-alat bukti hukum yang sah menurut Pasal 184 (1) Kitab Undang-Undang Hukum Acara Pidana.

Di dalam teori pembuktian berdasarkan Undang-Undang secara negatif terdapat 2 (dua) hal yang menjadi syarat, yaitu sebagai berikut. ${ }^{12)}$

a. Wettelijk, oleh karena alat-alat bukti yang sah dan yang ditetapkan oleh undang-undang.

b. Negatief, oleh karena dengan alat-alat bukti yang sah dan diterapkan oleh undang-undang saja belum cukup untuk memaksa hakim pidana menganggap bukti sudah diberikan, tetapi masih dibutuhkan keyakinan Hakim. Dengan demikian, antara alat-alat bukti dan keyakinan Hakim diharuskan adanya hubungan kausal (sebab akibat).

\footnotetext{
${ }^{12)}$ Alfitra. Op Cit, hal. 156.
} 
Jika dihubungkan dengan beberapa contoh kasus yang telah Peneliti uraikan di atas, pertimbangan Hakim untuk menjadikan CCTV sebagai alat bukti tentu harus sesuai dengan teori pembuktian berdasarkan Undang-Undang secara negatif ataupun Pasal 183 Kitab Undang-Undang Hukum Acara Pidana. Di mana syarat pertama yaitu wettelijk adalah terdapat alat-alat bukti berupa keterangan saksi dan keterangan terdakwa yang merupakan bagian dari alat bukti hukum yang sah sesuai dengan Pasal 184 (1) Kitab Undang-Undang Hukum Acara Pidana. Selain diperolehnya alat bukti berupa keterangan saksi dan keterangan terdakwa. Keterengan saksi di dalam beberapa contoh kasus tersebut juga menyebutkan alat bukti lain yaitu berupa CCTV yang dijadikan sebagai petunjuk untuk memberi penjelasan atas kejadian pada saat itu dalam beberapa kasus tersebut. Syarat kedua, yaitu negatief adalah persoalan mengenai keyakinan Hakim. Hakim harus mempunyai keyakinan atas alat-alat bukti yang terdapat dalam persidangan bahwa alat-alat bukti tersebut menjelaskan secara benar dan perbuatan pidana telah terjadi. Terlebih, dalam penggunaan CCTV pada beberapa contoh kasus tersebut, Hakim dalam mempertimbangkan bahwa CCTV tersebut dapat dipergunakan sebagai alat bukti, Hakim harus menyesuaikan keterkaitan antara CCTV tersebut dengan keterangan saksi dan keterangan terdakwa. Karena, CCTV tersebut dipergunakan sebagai alat bukti petunjuk yang menjadi perluasan atas keterangan saksi dan keterangan terdakwa pada beberapa contoh kasus tersebut. Sehingga, Hakim dalam mempertimbangkan bahwa CCTV dapat dipergunakan sebagai alat bukti hukum yang sah harus meyakinkan dirinya bahwa benar CCTV tersebut mempunyai keterkaitan antara keterangan saksi dan keterangan terdakwa. Jika, Hakim telah memperoleh keyakinannya, Hakim baru dapat memutus bahwa suatu tindak pidana telah benar-benar terjadi dan Terdakwa yang benar telah melakukannya sebagaimana telah dibuktikan melalui alat-alat 
bukti yang ada dan diperjelas melalui gambar-gambar berjalan di dalam CCTV tersebut.

Demikian, dalam wawancara Peneliti terhadap beberapa narasumber, para narasumber juga menyatakan bahwa sebenarnya alat bukti petunjuk sebenarnya terletak pada pemikiran Hakim. Hanya Hakim yang menentukan bahwa alat bukti petunjuk tersebut dapat dipergunakan atau tidak. Dalam, beberapa contoh kasus yang telah Peneliti jelaskan di atas, bahwa CCTV dalam hal ini dipergunakan sebagai alat bukti petunjuk. Tetapi, Hakim pada dasasrnya tetap mempertimbangkan apakah CCTV tersebut layak dijadikan sebagai alat bukti atau tidak. Sehingga, Hakim merujuk kembali pada Pasal 188 Kitab Undang-Undang Hukum Acara Pidana, bahwa alat bukti petunjuk yang dalam kasus-kasus ini adalah CCTV, Hakim mengaitkan CCTV tersebut berdasarkan keterangan saksi dan keterangan terdakwa. Karena, Hakim merasa CCTV tersebut mempunyai keterkaitan atas fakta yang diberikan oleh keterangan saksi dan keterangan terdakwa dan diperjelas oleh gambar-gambar bergerak pada CCTV, maka Hakim menentukan bahwa CCTV tersebut dapat dijadikan sebagai perluasan dari alat bukti petunjuk di dalam beberapa kasus di atas.

Sehingga, dari hasil wawancara sebagai berikut, Peneliti juga berpendapat sama atas pendapat-pendapat yang telah diberikan oleh beberapa narasumber tersebut. Peneliti berpendapat bahwa memang benar pertimbangan Hakim dalam menentukan CCTV sebagai alat bukti tersebut harus didasarkan pada Pasal 188 Kitab Undang-Undang Hukum Acara Pidana. Bahwa, mengenai CCTV tersebut harus mempunyai keterkaitan atas apa yang dinyatakan oleh Pasal 188 Kitab Undang-Undang Hukum Acara Pidana barulah Hakim dapat mempertimbangkan CCTV sebagai alat bukti perluasan dari alat bukti petunjuk yang dipakai dalam beberapa kasus yang telah Peneliti uraikan di atas. 


\section{PENUTUP}

\section{A. Kesimpulan}

Sejak disusun dan dilakukan perumusan permasalahan dari Bab I sampai dengan bagian pembahasan yaitu analisis terhadap permasalahan yang dikemukakan berdasarkan teori-teori dan pendapat yang telah diberikan oleh para narasumber dapat disimpulkan bahwa seiring perkembangannya zaman yang begitu pesat, harus dibutuhkannya alat-alat bukti yang membantu mempermudah dalam menangani permasalahan-permasalahan yang terjadi khususnya dalam permasalahan pidana. Maka, CCTV dalam hal ini adalah suatu alat bukti yang dibutuhkan pada zaman ini yang dapat mempermudah dalam membuktikan apakah perbuatan pidana tersebut telah benar-benar terjadi atau tidak. Tentu, CCTV untuk dapat dijadikan sebagai suatu alat bukti petunjuk tetap harus berpedoman dari Pasal 188 Kitab Undang-Undang Hukum Acara Pidana di mana CCTV harus diperoleh atau mempunyai keterkaitan dengan keterangan saksi, surat, maupun keterangan terdakwa. CCTV yang mempunyai keterkaitan tersebut dapat dijadikan sebagai alat bukti petunjuk untuk memberi pencerahan atau memperjelas apa yang telah diperoleh dari keterangan saksi, surat, maupun keterangan terdakwa.

Dalam hal demikian, Hakim juga harus mempertimbangkan CCTV sebagai alat bukti. Hakim harus memperoleh keyakinan atas CCTV tersebut untuk dapat dijadikan sebagai alat bukti petunjuk yang sah. Hakim harus melihat apakah CCTV tersebut berkaitan dengan keterangan saksi, surat, maupun keterangan terdakwa. Hakim dapat menentukan bahwa CCTV tersebut dapat dijadikan alat bukti atau tidak. Jika CCTV tersebut memang berkaitan dengan keterangan saksi, surat, maupun keterangan terdakwa, maka Hakim dapat menjadikan CCTV tersebut sebagai alat bukti yang sah dan Hakim juga dapat memperoleh keyakinan bahwa tindak pidana tersebut telah benar-benar terjadi yang tentu diperkuat karena adanya CCTV yang memperjelas peristiwa tersebut. 
William Abraham \& Hery Firmansyah

Analisis Pembuktian Alat Bukti Closed Circuit Television (CCTV)

Sebagai Alat Bukti Petunjuk

\section{B. Saran}

Demi terciptanya kepastian hukum, Peneliti berpendapat bahwa perlunya diperjelas dalam Undang-Undang Nomor 11 Tahun 2008 Tentang Informasi dan Transaksi Elektronik mengenai penggunaan dari CCTV tersebut di dalam persidangan, guna dapat menimbulkan kepastian hukum dan memperjelas dalam penggunaan CCTV sebagai alat bukti dalam setiap kasus-kasus pidana terutama kasus-kasus pidana yang berkaitan dengan CCTV.

\section{Daftar Pustaka}

\section{A. Buku}

Fuady, Munir. Teori Hukum Pembuktian (Pidana dan Perdata). (Jakarta: Citra Aditya Bakti, 2012).

Hiariej, O.S.Eddy. Teori dan Hukum Pembuktian. (Jakarta: Erlangga, 2012).

Subekti, R. Hukum Pembuktian. (Jakarta: Pradnya Paramita, 1987).

Waluyo, Bambang. Sistem Pembuktian Dalam Peradilan Indonesia. (Jakarta: Sinar Grafika, 1992).

\section{B. Peraturan Perundang-Undangan}

Indonesia. Undang-Undang Nomor 8 Tahun 1981 tentang Kitab UndangUndang Hukum Acara Pidana. (Lembaran Negara Republik Indonesia Tahun 1981 Nomor 76, Tambahan Lembaran Negara Republik Indonesia Nomor 3209).

- Undang-Undang Nomor 11 Tahun 2008 tentang Informasi dan Transasksi Elektronik (Lembaran Negara Republik Indonesia Tahun 2008 Nomor 58, Tambahan Lembaran Negara Republik Indonesia Nomor 4843).

\section{Putusan}

Indonesia. Putusan Mahkamah Agung (No. 1989K/Pid.Sus/1989).

. Putusan Mahkamah Konstitusi (No. 20/PUU-XIV/2016)

. Putusan Pengadilan Negeri (No.11/PID/B/2015/PN.SKY).

Putusan Pengadilan Negeri (No.127/PID.B/2015/PN.TLG).

. Putusan Pengadilan Negeri (No.777/PID.B/2016/PN.JKT.PST). 